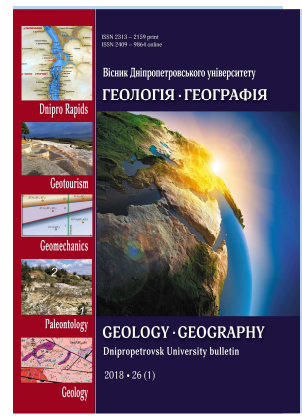

Geology $\bullet$ Geography

Dnipro university bulletin

Journal home page: geology-dnu-dp.ua
ISSN 2313-2159 (print)

ISSN 2409-9864(online)

Dniprop. Univer.bulletin.

Geology, geography., 26(1), 165-175.

doi: $10.15421 / 111818$

Sergiy P. Son'ko

Dniprop. Univer. bulletin, Geology, geography., 26(1), 165-175.

\title{
Сільськогосподарське районування Харківської області: географічна проблема - екологічні наслідки
}

\section{С. П. Сонько}

Уманський національний університет садівництвва, Умань, Україна, е-таil: Sp.sonko@gmail.com

Received 13.12.2018

Received in revised form 10.01 .2018

Accepted 18.01.2018
Анотація. Виробнича типологія і сільськогосподарське районування - один із найдавніших і найактуальніших напрямів географічної науки, який намагається вирішити проблему відповідності наявної спеціалізації природним можливостям території. На сьогодні спеціалізація головного масиву господарств лісостепової зони (понад 85 \% загальної кількості) наближається до монокультурної (виробництво зернових та олійних культур). Це стало наслідком того, що ринкова економіка за останні 20 років об'єктивно «вимила» 3 переліку галузей спеціалізації галузі тваринництва, які завжди (за рахунок органічних добрив) забезпечували екологічну стабільність агроекосистем. Сучасні ж дослідження з енергетики агроекосистем свідчать про можливість екологізації сільськогосподарського виробництва саме за рахунок диверсифікації його спеціалізації. Об'єктивні умови для цього створює сама природа, «закладаючи» в кожний природний ландшафт відповідний агрокліматичний потенціал. Головне завдання пропонованої статті - відповідь на запитання: наскільки реальна спеціалізація сільськогосподарських підприємств Харківської області відрізняється від природно зумовленої. Визначним бачиться те, що подібні дослідження автор проводив на території області (в руслі написання кандидатської дисертації) 30 років тому. Це дало змогу порівняти стан агроекосистем тридцятирічної давнини з теперішнім. Стаття стала продовженням авторського циклу праць, присвячених дослідженню впливу виробничої типології сільського господарства на екологічний стан агроекосистем.

\section{Agricultural Districts of the Kharkiv Region: Geographical Issues - Environmental Consequences}

\section{S.P. Son'ko}

Uman National University of Horticulture, Uman, Ukraine e-mail: Sp.sonko@gmail.com

\begin{abstract}
The industrial typology and agricultural zoning is one of the oldest and most urgent areas of geographic science, which tries to solve the problem of matching the existing specialization with the natural opportunities of the territory. Today, the specialization of the main massif of farms in the forest-steppe zone (more than $85 \%$ of the total) is near monocultural (production of grain and oilseeds). This was a consequence of the fact that the market economy objectively "wasted" in the last 20 years from the list of specialization branches of the livestock sector, which always (due to organic fertilizers) ensure ecological stability of agroecosystems. Modern studies on the energy of agroecosystems show the possibility of environmentalization of agricultural production by the diversification of its specialization. The objective conditions for such diversification are the nature itself, "lining" in each natural landscape the corresponding agro-climatic potential. The main task of the proposed article is the answer to the question - how much the real specialization of agricultural enterprises in Kharkiv region differs from the natural predetermined. It is noteworthy that such studies were carried out by the author on the territory of the region (in the course of writing a candidate's dissertation) 30 years ago. This made it possible to compare the state of agro-ecosystems of thirty years ago with their present state. The article is a continuation of the author's cycle of works devoted to the study of the influence of the industrial typology of agriculture on the ecological state of agroecosystems.
\end{abstract}

Keywords: geographical, agricultural, typology, zoning, agroclimatic, agroecosystem

Актуальність дослідження. Проблема, на розв'язання якої спрямоване наше дослідження, має високий рівень актуальності, оскільки умови ринкової економіки, у яких розвивається сільське господарство, примушують сільгоспвиробників у гонитві за прибутком розвивати галузі 
спеціалізації, які не відповідають агрокліматичному потенціалу території (Orozco-Ramírez, Astier, Barrasa, 2017; Rivieccio, Sallustio, Paolanti, Vizzarri, 2017). Така невідповідність не лише спричинює екологічні наслідки, як то катастрофічне погіршення природної родючості грунтів, а й, у підсумку, відбивається на ефективності галузі (Almeida, Mourão, Dessay, Lacques, Monteiro, Durieux, Venturieri, Seyler, 2016).

В умовах лісостепової зони, як своєрідного переходу між Лісом та Степом, визначення оптимальної спеціалізації завжди являло собою складну наукову проблему. А в умовах Харківської області, територія якої розташована в лісостеповій (північ) і степовій (південь) природних зонах одночасно, вказана проблема загострюється ще більше. Ця проблема бачиться актуальною ще й 3 тих позицій, що в останні роки в науковому географічному середовищі триває активна дискусія навколо антропогенної складової природних ландшафтів. Зокрема, згідно 3 Г. Денисиком (Denysyk,2001) сучасних меж між Степом і Лісостепом не існує, оскільки активна антропогенна діяльність (передусім сільськогосподарська) ці межі «розмила», перетворивши увесь простір від Десни до гирла Дунаю на суцільне Лісополе. На нашу думку, саме сільськогосподарська діяльність є тією індикаторною галуззю, яка, попри суттєвий вплив економічних факторів, найяскравіше може розкрити вплив природної складової на формування господарської спеціалізації. Ця проблематика традиційно перебуває в предметній галузі конструктивної географії.

Отже, головна проблема дослідження, яка, власне, і визначає іiі актуальність, - удосконалення існуючої виробничої спеціалізації господарств лісостепової зони України (Харківська обл.) залежно від природних і економічних умов, в яких вони розвиваються.

Пошук і наукове обгрунтування таких поєднань галузей спеціалізації на рівні окремого господарства, які б були екологічно толерантними і в той же час забезпечували максимальну продуктивність агробіоценозів, формують новизну цього наукового дослідження. Вперше за період української незалежності виконано виробничу типологію і сільськогосподарське районування Харківської області.

Формування мети дослідження виходить 3 уявлення про те, що в умовах Лісостепу України (зокрема, у Харківській області) існує невідповідність виробничої спеціалізації сільського господарства і ресурсів природних екосистем. Відтак, наше дослідження спрямоване на подолання такої невідповідності.
Зокрема, наукове обгрунтування адаптованих до умов Лісостепу Харківської області складових агроекосистем вимагає виконання таких наукових завдань:

- дослідження сучасної спеціалізації (виробничих типів) сільськогосподарських підприємств Харківської області з наступним сільськогосподарським районуванням;

- оцінювання рівня екологічно-шкідливого впливу кожного 3 підприємств на агроландшафти з наступним районуванням території Харківської області за цим показником;

- наукове обгрунтування застосування технологій екологічної конверсії для створення екологічно толерантних агроекосистем в умовах сільського господарства як Харківської області, так і усього Лісостепу України.

Очікувана на виході таких агроекосистем висока біопродуктивність, отримана завдяки біологізації землеробства і зумовлює практичне значення нашого дослідження.

Це наукове дослідження виконувалось у межах науково-дослідницької програми Уманського національного університету садівництва «Розробка методологічних підходів і практичного механізму еколого-збалансованого природокористування у сфері аграрного виробництва» (№ ДР 0108U009772). В межах вказаної науководослідницької програми у 2016 році був також виконаний грантовий науковий проект «Геоінформаційне моделювання типології сільського господарства Лісостепу України з метою розробки екологічно толерантних агроекосистем» (http: // lib. udau. edu. ua/handle/123456789/6194). Раніше ця проблема досліджувалась на території деяких адміністративних одиниць РФ (Karjagin,2013, Bryzhko, Shkrebko, 2010), Черкаської області (Son'ko, 2015), у 2017 році - на території Харківської області, наступного року на території Кіровоградської області. До 2020 року планується дослідити цю проблему у всіх областях лісостепової зони України. В цій статті публікуються результати виконання першого завдання, а саме, дослідження сучасної спеціалізації (виробничих типів) сільськогосподарських підприємств Харківської області 3 наступним сільськогосподарським районуванням.

Передумови. Перший період активності у розробленні проблем типології і районування сільського господарства припадає на 50--70-ті роки XX століття і збігається 3 початком так званої «зеленої революціï» (Kostrovickij, 1970), яка поклала початок екстенсивному освоєнню агрокліматичних ресурсів Світу. В період із 70-х по 80ті роки як у Радянському Союзі (А. Ракітніков, В. Крючков, Ф. Зальцман), так і в Україні (I. Муко- 
мель) виконано систематичне дослідження типології сільського господарства для більшості регіонів. 3 посиленням інтенсифікації сільського господарства проблема відповідності наявної спеціалізації певному агрокліматичному потенціалу відійшла на другий план, про небезпеку чого неодноразово вказувалось у працях авторитетних учених (Coughlan, Nelson, Lonneman, Block, 2017; Gudz', Shuvar, Junyk, Ryhlivs'kyj, Mishhenko,2014; Gutorov, 2015; Ljashenko, 2011; Petrychenko, Zaryshnjak, Baljuk, Polupan, Velychko, Solovej, 2013; Tarariko, Glushhenko, 2011).

Проте ринкова економіка лише поглибила «прірву» між спеціалізацією сільського господарства і наявними можливостями агроландшафтів (Son'ko, 2015; Orozco-Ramírez Q., Astier M., Barrasa S., 2017). Сучасне відновлення інтересу до вказаної проблематики (або початок другого періоду) зумовлене, передусім, екологічною некоректністю моделі «зеленої революції», слідування якій впродовж останніх 30 років сьогодні дається взнаки і має прояв, головно, у небезпечній динаміці зниження вмісту гумусу у грунтах (Sweeney, 2017; Petrychenko, Zaryshnjak, Baljuk, Polupan, Velychko, Solovej, 2013; Son'ko, 2017).

За вказані 30--40 років брак земельних ресурсів у розвинутих країнах для подальшого впровадження інтенсивних технологій компенсується освоєнням нових земель (тобто розвиток «ушир») у країнах третього світу, до яких сьогодні вже потрапляє й Україна. Саме тому в сучасних дослідженнях(Son'ko, 2015, 2017) наголошується на необхідності перестановки наголосів у сільськогосподарському природокористуванні 3 традиційного «збільшити врожайність» на «зберегти біоресурси для майбутніх поколінь».

Однією 3 головних причин кризового стану називається саме невідповідність наявної спеціалізації природно ресурсному потенціалу сільського господарства (Ibatullin, Shanin, Stepenko,2014). При цьому вказана проблема тягне за собою низку інших - глобальної зміни клімату, збіднення біорізноманіття, накопичення нітратів та пестицидів у грунтах, евтрофікація водойм та втрата грунтами гумусу (Heckrath, Djurhuus, Quine, Van Oost, Govers, Zhang, 2004).

Відтак, сучасні дослідження типології сільського господарства повинні стати першим кроком на шляху до гармонізації відносин природи і суспільства, причому вже на новому методологічному рівні - із впровадженням екологічно толерантних технологій екологічної конверciï (http://lib.udau.edu.ua/handle/123456789/6257).

Виклад основного матеріалу. Головний об'єкт дослідження -- виробнича спеціалізація господарств Харківської області, яка цікава автору ще й тому, що подібні дослідження він проводив по цій території 30 років тому (під час роботи над кандидатською дисертацією, Son'ko, 1990). При цьому доцільним бачиться розгляд спеціалізації (виробничого типу) не лише як певного набору галузей сільського господарства, а й рівня його відповідності агрокліматичному потенціалу певної території (зональність) (Ljashenko, 2011; Ibatullin, Shanin, Stepenko, 2014).

Умови проведення дослідження відповідали агрокліматичним умовам Лісостепу України. При цьому автор свідомо не розділяє лісостеп на правобережний і лівобережний для того, щоб перевірити методичні підходи, розроблені в процесі дослідження на різних територіях (Gutorov, 2015; Son'ko, 2015).

Єдине, що суттєво відрізняє досліджувану територію від попередньої - це проходження межі степу і лісостепу посередині області. При цьому, у зв'язку з глобальним потеплінням, ця межа поступово зсувається на північ, що відмічено в попередніх дослідженнях (Son'ko, 2015).

Методика проведення досліджень детально викладена у цілому переліку авторських публікацій починаючи 3 кінця 1980-х років. Останні 3 них датовані 2015--2017 роками (Son'ko, 2015, 2017). Основу методики склали сучасні геоінформаційні технології (зокрема, методика ЕГІС, розроблена автором -- Son'ko, 2000, 2017) та моделі просторової інтерполяції (полігони Тіссена--Вороного). За відсутності детальної інформації щодо суцільного масиву господарств як основне ii джерело були використані Інтернет-ресурси, на яких розміщена маркетологічна інформація про кожне господарство (www//http: anyfoodanyfeed.com; www//http:kolosok.info; https://tripoli.land; https: // ukrmap. org/year2016/5367.html).

Дослідження тенденцій землекористування як в Україні, так і в інших країнах за роки розвитку ринкових відносин свідчать про те, що виробнича спеціалізація сільського господарства обирається не відповідно до природних можливостей певного агробіоценозу, а згідно з ринковими інтересами (тобто для отримання максимальних прибутків). Аналізуючи впродовж понад 20 років цю, загальну для усього світового сільського господарства проблему, автор зробив таке:

- за напрямом: розроблено теоретичні підвалини розвитку сільського господарства у складі просторових соціо природних систем більш високого рівня організації (Son'ko, 2003).

Розроблено концепцію ноосферних екосистем, у переліку яких сільське господарство формує найскладнішу і найдинамічнішу агрорекосистему, яка за типом речовинно-енергетичного 
обміну найбільше наближається до біосферних механізмів (Son'ko, 2010).

- за проблемою: визначено головні напрями коректної постановки і подальшого вирішення екологічної проблеми, в тому числі в сільському господарстві (Son'ko, 2010).

- за тематикою: досліджено головні причини загострення екологічної проблеми в галузях сільського господарства (Son'ko, Maksymenko, 2012).

- за об'єктом: встановлено механізми шкідливого впливу сільського господарства на природні ландшафти (Son'ko, Maksymenko, 2013).

- за предметом: визначено головні шляхи і засоби подолання екологічних проблем у сільському господарстві (Son'ko, Golubkina, 2014; Son'ko, 2015).

Здійснено популяризацію ідеї екологічнотолерантного сільського господарства (Son'ko, 2016).

Виходячи 3 аналізу вказаної проблеми, альтернативою енерговитратному сільському господарству можуть стати екологічно толерантні агроекосистеми, концептуальні підвалини і практичний механізм упровадження яких автор розробляє впродовж останніх років (Son'ko, 2015; Son'ko, 2017; Son'ko S.P., Suhanova, 2015).

Наукове дослідження, презентоване в цій статті, $є$ другою частиною більш масштабного (за охопленням територіі) наукового проекту. На наступних етапах передбачено проведення подібних досліджень в інших областях лісостепової зони України (Кіровоградська, Вінницька, Полтавська, Київська, Хмельницька, Тернопільська). Виробнича типологія сільськогосподарських підприємств Харківської області. У Харківській області на 2014--2015 рік нараховувалось 1 617 сільськогосподарських підприємств. На відміну від популярного в останні роки методу середньозваженого рангу, в якому застосовується механічна градація галузей (Lihvan V., Dobrovol's'ka N., Kandyba, 2013), в нашому випадку визначення спеціалізації торкається самих підвалин розвитку сільського господарства залежно від природних і економічних умов. Згідно з таким підходом, головним критерієм визначення спеціалізації вважається рівень зональності галузі, який в нашому випадку визначався за 5-бальною шкалою. Зокрема, якщо згідно агрокліматичними вимогами умови лісостепу найбільше від-

\footnotetext{
2 Агрокліматичне районування - науково обгрунтований поділ території за агрокліматичними умовами вирощування сільськогосподарських культур. За допомогою агрокліматичного районування виділяють території із сприятливими, задовільними чи несприятливими кліматичними умовами для вирощування тієї чи іншої культури і визначають продуктивність клімату в показниках відносної
}

повідають вирощуванню зернових культур та соняшнику, рівень зональності оцінювався в 5 балів (Son'ko, 2017) ${ }^{2}$.

Визначення зональності тваринництва більш складна дослідницька процедура, оскільки його зональність залежить не лише від товарності продукції. Зокрема, найвищим ступенем зональності володіє скотарство, оскільки саме там ще збереглося безприв'язне утримання худоби з використанням рослинних ресурсів природних кормових угідь. Натомість, свинарство, птахівництво, кролівництво за типом кормової бази мало пов'язані з природними кормовими угіддями i можуть розвиватись майже повсюдно.

Отже, покладатись для визначення спеціалізації тваринництва лише на дані, які публікують про свої господарства фермери, недостатньо, оскільки вони враховують лише товарність продукції. Врахування ж природної складової формування спеціалізації тваринництва вимагає передусім дослідження структури раціонів годівлі і структури стада. В більшості випадків в умовах Лісостепу в господарствах, що заявили про себе як «молочні», формується молочном'ясна спеціалізація і далі, в умовах степу - ті, що заявили про спеціалізацію як про «молочном'ясну», реально мають м'ясо-молочну.

Справа в тім, що природні умови для розвитку молочного скотарства у чистому вигляді існують в Данії, Голландії, північних департаментах Франції, в деяких районах Великобританії, де наявні значні площі природних кормових угідь як джерела соковитих кормів за безприв'язного утримання худоби. Крім того, в цих країнах набагато краще розвинута племінна справа і господарі молочних ферм не змушені тримати ремонтний молодняк на відгодівлі у власному господарстві.

В умовах же вітчизняного скотарства відбувається постійне вибракування молочного стада, яке замінюється ремонтним молодняком переважно власного утримання. В більшості випадків вибракувану худобу забивають для внутрішньогосподарського споживання і «не показують» у структурі товарної продукції. Відтак, реальна структура стада у «молочно-м'ясних» господарствах наближається до м'ясо-молочної.

Вказану особливість ми врахували. При цьому спеціалізація скотарства була також скоригована залежно від наявності у господарстві

врожайності. Знання агрокліматичних особливостей дає змогу якнайдоцільніше розміщувати сільськогосподарські культури і застосовувати найдосконаліші меліоративно-агротехнічні заходи (Ljashenko,2011). 
природних кормових угідь, що, в свою чергу залежить від розміщення території у степовій чи лісостеповій зоні, наявності заплавних територій чи розвитку яружно-балочної системи.

При визначенні виробничого типу нами були здійснені рутинні дослідницькі процедури, необхідні в таких дослідженнях і описані в попередніх роботах (Son'ko, 1990-2015). Зокрема, всі галузі були розбиті на два найголовніші напрямки - рослинництво і тваринництво. При цьому «чисто» рослинницьким господарствам при визначенні виробничого типу віддавався пріоритет, оскільки на продуцентів в екосистемах припадає понад 98\% фіксованої сонячної енергіï, а, отже, 3 географічної точки зору саме рослинництво в найбільшому ступені визначає рівень зональності («вписання» в природний ландшафт) підприємства. Другий за значенням критерій - рівень інтенсивності, або ж розмір сумарних витрат, зокрема, енергетичних субсидій на підтримку певної галузі. Зокрема, за цим критерієм господарства, в яких розвивають тваринництво (хоч самостійно, хоч у сполученні 3 рослинництвом) $€$ більш енерговитратні порівняно 3 «чисто» рослинницькими. Так само в рослинницьких господарствах за наявності просапних технічних культур також зростає рівень інтенсивності.

Наведені методичні прийоми були застосовані на території Харківської області, яка цікава автору ще через ту обставину, що подібні дослідження (в руслі написання кандидатської дисертаціi) він провів у період з 1980 по 1990 рік, (Son'ko,1990). Загальна тенденція до збільшення кількості землекористувачів - 1617 сьогодні, порівняно з 429 у 1985 році наче б то дає слабку надію, що в сучасному сільському господарстві наявне прагнення до «вписання» спеціалізації у природні ландшафти. Проте закони ринку геть руйнують такі сподівання і замість 25 виробничих типів, виділених автором на території області у 1985 році (серед яких понад половина мали високий ступінь зональності), сьогодні виділяється щонайбільше 10 типів, «зональність» яких підлягає великим сумнівам.

\footnotetext{
3 Серед цих підприємств близько 20 \% припадає на ті, що заявили про свою спеціалізацію як «Зернові та технічні культури». Враховуючи, що головною технічною культурою в Лісостепу України $\epsilon$ соняшник, а також на підставі консультацій з окремими фермерами і спеціалістами сільського господарства районів Харківської області назва типу була узагальнена саме таким чином. Виняток складають підприємства що вирощують ріпак (або замість, або разом із соняшником). Господарства, що заявили про себе як ті, що вирощують цукровий буряк (знову ж таки, переважно разом із соняшником чи ріпаком), виявились нечисленними (67) і «розпорошеними» по території області, а, отже, можуть лише незначним чином впливати на рівень зональності типу.
}

В одній з ранніх авторських праць (Son'ko, 2015) були досліджені типи використання земель, типи організації сільськогосподарської території, виробничі типи господарств та сільськогосподарські райони (усе в розрізі господарств), які формуються на території Харківської області. Головним дослідницьким інструментом стала ЕГІС, методика якої розроблена в попередніх дослідженнях (Son'ko, 2000). Застосування пропонованої методики дає змогу в процесі визначення певного виробничого типу використовувати гіперпосилання (рис. 1).

Основу рослинницьких виробничих типів склали господарства, які спеціалізуються на вирощуванні зернових колосових культур і соняшнику і яких налічується в області $848^{3}$. Буряківництво, попри розвиток у 67 господарствах, в окремий тип не виділялось, оскільки у всіх господарствах, де воно розвинене, воно перебуває на другорядних місцях після зернових, соняшнику або ж різних галузей тваринництва.

Серед рослинницьких на другому місці ті, що спеціалізуються на виробництві зернових культур (417), або зернових із кукурудзою (57). Виділення в окремий тип зернових із кукурудзою зумовлене тим, що кукурудза - просапна культура і вимагає додаткових енергетичних субсидій, зокрема, для міжрядного обробітку.

У переліку виробничого типу із зерновими культурами найчастіше зустрічаються підтипи в поєднанні з садівництвом / виноградарством i овочівництвом / картоплярством, або 3 вирощуванням кормових культур, або виробництвом міцелію гливи, або з вирощуванням баштанних культур (33 господарства). В перелічених типах рівень зональності ми оцінили в 4--5 балів. Далі у напрямку зниження рівня зональності, a, отже, збільшення рівня інтенсивності у нашій типології розміщені підприємства, що спеціалізуються на овочівництві (13), садівництві (6) та рисосіянні (5) 4 . В окремий тип, який займає середнє положення за рівнем зональності та інтенсивності, були об'єднані господарства, що спеціалізуються на насінництві, яке вимагає додержання

\footnotetext{
4 Вирощування рису - напевне, найбільш «екзотичний» тип для умов Харківської області (хоч би тому, що світові ареали рисосіяння припадають на зони з тропічним кліматом). Зокрема, це господарства: «Берізка» (Руська Лозова, Дергачівський район,), к-т «Тепличний» (Есхар, Чугуївський район), а/ф «Українське насіння» (Красне, Кегичівський р-н), ПАТ «Ізюмське» (Федорівка Ізюмського району), ТОВ Красноградська овочева фабрика (Наталіне, Красноградський район). Проте консультації з експертами підтвердили можливість рисосіяння і в умовах помірного клімату, але замість чеків у нашому випадку використовувались заплави малих річок і заливні луки. Між тим, на думку експертів, економічна ефективність цієї галузі в умовах степу та лісостепу підлягає великим сумнівам.
} 
певної технології, пов'язаної з ізоляцією посівів (всього 17 господарств). Господарств, що спеціалізуються лише на тваринництві у «чистому» вигляді, дуже мало (6). Це ті, де розвивається свинарство (1), птахівництво (1), бджільництво (1), конярство (1), або ж племінні господарства (2).

Найбільш різноманітними за кількістю сполучень галузей виявились рослинницько-тваринницькі виробничі типи із середнім рівнем зональності 4 бали. Це:

- зернові, соняшник, скотарство м'ясо-молочного напрямку (62), з рівнем зональності 4--5 балів;

- Зернові, соняшник, скотарство молочном'ясного напрямку (84), з рівнем зональності 3-4 бали (залежно від розміщення по відношенню до крупних центрів споживання незбираної молочної продукції - Харків, Куп'янськ, Красноград та ін., або ж за наявності природних кормових угідь);

- Зернові, соняшник, свинарство (43), з рівнем зональності 3 бали.

Як допоміжні галузі тваринництва 3 низьким рівнем зональності доволі часто зустрічаються птахівництво (18), рибництво (17), бджільництво (8), вівчарство (6). При цьому на перших місцях можуть бути різноманітні галузі рослинництва і тваринництва: вирощування зернових, соняшнику, овочівництво, садівництво, скотарство, свинарство, та ін.

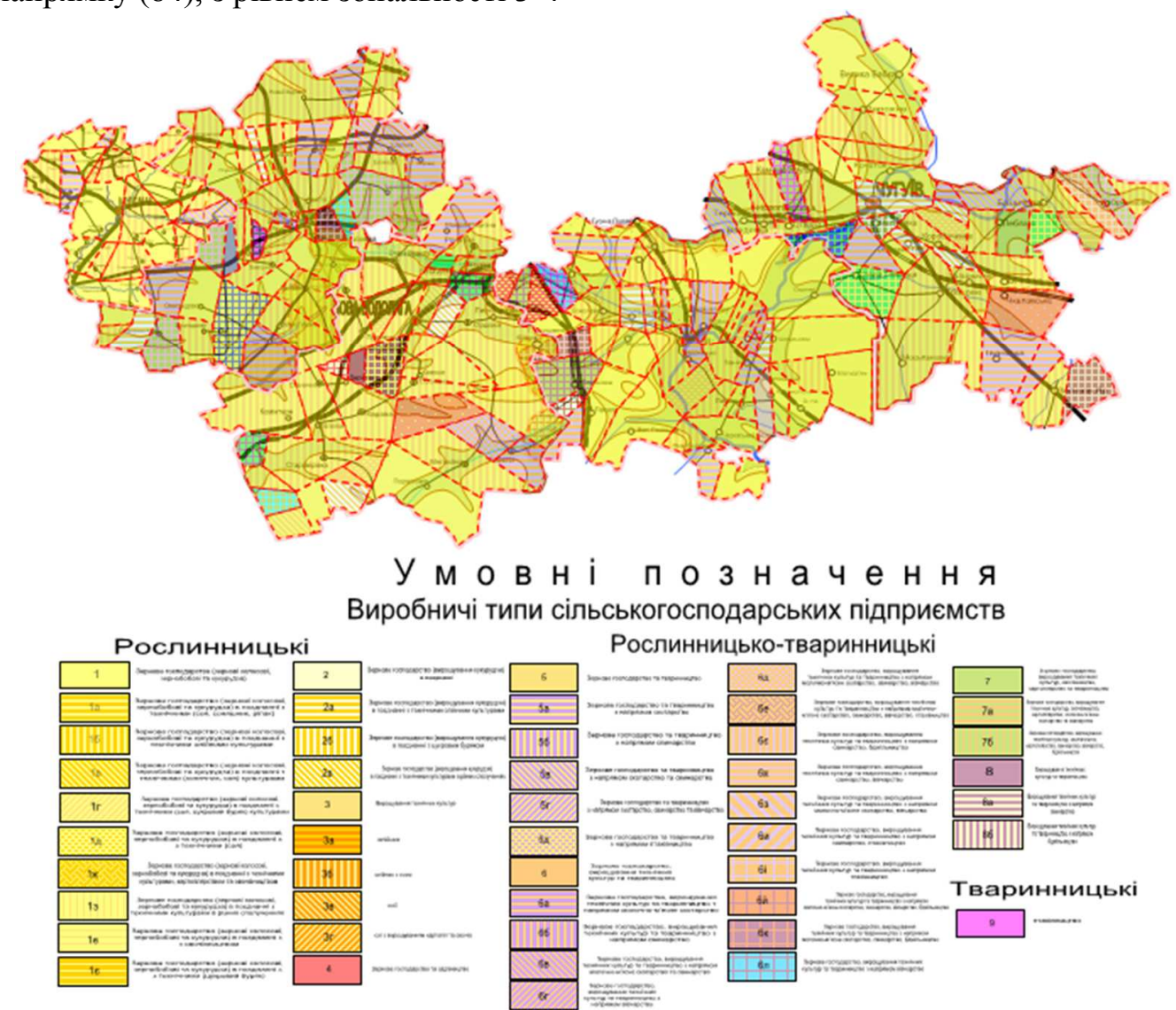

Рис.1. Візуалізація гіпертексту в ЕГІС «Виробничі типи сільськогосподарських підприємств Харківської області, станом на 2015 р.р.» (фрагмент)

Скоріше як виняток зустрічаються господарства 3 дуже різноманітною спеціалізацією, наприклад, ТОВ «Близнюківський комбікормовий завод» - «Зернові, соняшник, свинарство племінне (Полтавська біла), буряківництво, скотарство м'ясо-молочного напряму», чи в тому ж Близнюківському районі ТОВ «Лан» - «Зернові, соняшник, скотарство м'ясо-молочного напряму, свинарство, вівчарство, буряківництво», або в Богодухівському районі СТОВ «Батьківщина»- «Зернові, кукурудза, насінництво зернових, племінне скотарство молочного напрямку
(Українська червоно-ряба, симентал) свинарство, бджільництво, птахівництво (гуси), або в Сахновщинському районі ПАТ «Племінний завод ім. 20-річчя Жовтня» - «Цитрусові, зернові, соняшник, м'ясо-молочне скотарство, свинарство, буряківництво».

Проте такі господарства нечисленні (близько 15) і суттєво не впливають на рівень зональності основного масиву господарств області, оскільки економічна ефективність одночасного розвитку таких різноманітних за технологією галузей за оцінками експертів підлягає великим сумнівам. 
За результатами збирання й обробки даних та згідно 3 розробленою раніше методикою (Son'ko, 2015) ми створили елементарну ГІС (ЕГІС) виробничих типів сільськогосподарських підприємств Харківської області, яка стала інструментом для подальшого аналізу (рис. 2).

Сільськогосподарське районування території Харківської області.

Крім виробничих типів сільськогосподарських підприємств, для подальшого виділення сільськогосподарських районів ми також урахували природні особливості Харківської області, зокрема, агрокліматичне районування (Ljashenko,2011).

Крім традиційних зональних факторів, що формують тип «зернові з соняшником», на території Харківської області на формування сільськогосподарських районів суттєво впливають азональні фактори, такі як наявність потужного споживача (приміський тип сільського господарства), жорсткі умови ринкової економіки (бажання виробників отримати високий прибуток від продажу зернових, олійних культур, а також «екзотичних» видів продукції).

Станом на 2015 рік на території Харківської області ми виділили такі сільськогосподарські райони (рис. 2):

Зональні (3-4 бали):

I. Північно-Західний Лісостеповий. У складі Богодухівського, Краснокутського, Золочівського, Коломацького і частини Дергачівського адміністративних районів. 3 переважною спеціалізацією на виробництві зернових, олійних технічних (переважно соняшнику), цукрового буряку й окремих галузях тваринництва (молочно-м'ясного скотарства і свинарства). Важливо відмітити, що порівняно з 1985 роком (Son'ko, 2015) конфігурація цього району дещо змінилась, розтягнувшись у меридіональному напрямку, що пов'язано як із згортанням капіталомісткої цукрової промисловості, так і з відмовою більшості господарств від розвитку тваринництва. Певною мірою, у цьому районі буряківництво, скотарство і свинарство можна вважати «реліктовими» галузями зональної спеціалізації.

II. Північно-Східний Лісостеповий. У складі Вовчанського і північної частини Великобурлуцького районів. 3 переважною спеціалізацією на виробництві зернових, соняшнику й окремих галузях тваринництва (молочно-м'ясного скотарства і свинарства). Зональність спеціалізації забезпечують сприятливі агрокліматичні умови плакорних місцевостей межиріччя річок Вовча та
Бурлук, а також кормові ресурси долини річки Сіверський Донець. Головна просторова особливість формування тваринницької спеціалізації -це те, що господарства, в яких вона розвивається, витягнулись у суцільну смугу в широтному напрямі. Найскоріше це пов'язано з орієнтацією на мережу шляхів сполучення, які з'єднують ці господарства з потужним споживачем їх продукції (Харків, Куп'янськ, Вел. Бурлук, Вовчанськ).

III. Центральний Степовий. Найбільший за площею, у складі Зміївського, Первомайського, Сахновщинського, Зачепилівського, Лозівського, Близнюківського, західної частини Балаклійського, більшої частини Нововодолазького, північної частини Кегичівського і південної частини Чугуївського району ${ }^{5} .3$ переважною спеціалізацією на виробництві зернових, соняшнику (з розвинутим насінництвом), цукрового буряку і різноманітних галузях тваринництва (м'ясо-молочного скотарства, свинарства, птахівництва, племінної справи).

Названі галузі зональної спеціалізації доповнюють поодинокі господарства 3 нехарактерною для цієї природної зони: вирощування сої, овочів і фруктів, баштанних, кормових культур, цитрусових, рибництво, вівчарство, конярство. Їх розвиток пов'язаний, найскоріше, з бажанням виробників отримати швидкий прибуток від реалізації продукції «екзотичних» галузей, яка користується великим попитом на ринку (переважно м. Харків).

IV. Оскольсько-Сіверськодонецький Степовий. У складі Борівського, Ізюмського, Барвінківського, східної частини Балаклійського, південної частини Куп'янського районів. Спеціалізується на зональних галузях - вирощуванні зернових та соняшнику в рослинництві, свинарстві та м'ясо-молочному скотарстві у тваринництві. Але, на відміну від III району, в рослинництві (як підтипи) додаються садівництво, виноградарство, овочівництво, ягідництво, баштанництво, вирощування рису; у тваринництві - бджільництво, птахівництво, кролівництво, рибництво, племінне тваринництво. Розвиток саме цих (певною мірою азональних) галузей пояснюється, 3 одного боку унікальними агрокліматичними умовами межиріччя Сіверського Донця і Осколу, 3 іншого -- орієнтацією на густонаселені регіони Донецької області (Краматорськ, Слов'янськ, Дружківка).

Азональні (1--3 бали):

V. Харківський Приміський. У складі Харківського, більшої частини Дергачівського, більшої

\footnotetext{
${ }^{5}$ Цей район має просторове продовження на території Полтавської області.
} 
частини Чугуївського, західної частини Печенізького і північно-східної частини Нововодолазького районів. Спеціалізується на молочно-м'ясному і молочному скотарстві, овочівництві закритого і відкритого грунту, птахівництві, рибництві, садівництві. Названі галузі спеціалізації доповнюються доволі екзотичними для лісостепу галузями, такими як: виноградарство, вирощування цитрусових, міцелію гливи і печериці, кролівництво, вівчарство. Провідний фактор розвитку позначених галузей - це чітка орієнтація на потужний ринок збуту, яким є місто Харків. Відстань до споживача -- визначальна (азональна) умова розвитку перелічених галузей. И. Куп'янський Приоскольський. У складі Дворічанського, центральної і північної частини Куп'янського, північної частини Шевченківського, східної частини Печенізького, більшої частини Великобурлуцького районів. Спеціалізується як на зональних галузях рослинництва (зернові, кукурудза, соняшник), тваринництва (молочно-м'ясне скотарство та свинарство), так і на деяких азональних (овочівництво, садівництво, баштанництво - у рослинництві; птахівництво, бджільництво, вівчарство - у тваринництві). Розвиток саме такої спеціалізації зумовлений не лише агрокліматичними умовами північного степу, де розташований район, а й високим споживацьким потенціалом м. Куп'янськ, навколо якого традиційно впродовж останніх 50 років формується приміська спеціалізація.

VII. Красноградський Степовий. У складі Красноградського, більшої частини Кегичівського $\mathrm{i}$ двох господарств Зачепилівського району. Спеціалізується як на зональних галузях тваринництва (м'ясо-молочне скотарство та свинарство), так і рослинництва (зернові, кукурудза, соняшник). Розвинуте також насінництво зернових культур та соняшнику. Зважаючи на значний споживацький потенціал м. Красноград, розвинуті також такі галузі приміської (азональної) спеціалізації як овочівництво, садівництво, молочном'ясне скотарство, птахівництво. Серед «екзотичних» галузей представлене вирощування рису. На відміну від попереднього району, в структурі товарної продукції переважає продукція тваринництва.

Висновки. Аналіз розподілу сільськогосподарських підприємств по території Харківської області підтверджує відповідність (або невідповідність) головним природним та господарським закономірностям. Так, більша частина господарств із зерновою спеціалізацією «прив'язана» до плакорних пласких місцевостей центральної частини області. В районах, де розвинуті річкові долини із значними кормовими ресурсами, розвивається спеціалізація з орієнтацією на споживача і на значні ресурси зрошення - овочі відкритого грунту, молочно-м'ясне скотарство, птахівництво.

У ході дослідження проведене сільськогосподарське районування Харківської області (рис. 2), в результаті якого виділено сім районів, 3 яких чотири зональні та три азональні. Порівнюючи сучасну типологію сільського господарства Харківської області з виробничими типами, що були нами виділені у 1985 році (Son'ko, 2015), відмічаємо такі особливості:

1. За 30 років розвитку сільського господарства Харківщини його спеціалізація суттєво змінилась із переважно тваринницько-рослинницької (у 1985 р.) до рослинницької у 2015 році. Якщо у 1985 році переважали виробничі типи: скотарсько-буряківничі, скотарсько-зернові, скотарсько-олійницькі, скотарські та свинарські (до $85 \%$ усього масиву господарств), то у 2015 році всього на два типи -- зерно-олійні та зернові -- припадають ті ж 80--85\% господарств. Така тенденція пояснюється двома головними причинами. По-перше, демографічною кризою українського села, наслідком якої стала майже повна деградація трудомісткого тваринництва. I, по-друге, більш жорсткими законами ринкової економіки та глобалізаційними впливами, які об'єктивно «вимили» галузі з низьким диференційним доходом, залишивши експортно спроможні (Son'ko, 2015, 2017).

2. Порівняно з 1985 роком, коли різноманітні сполучення галузей тваринництва і рослинництва великою мирою визначали рівень зональності, у 2015 зональність визначають згадані вище дві галузі рослинництва - вирощування зернових та технічних олійних культур. Подібна тенденція вже давно притаманна країнам із високим ступенем розвитку капіталістичних відносин (Rivieccio, Sallustio, Vizzarri, Marchetti, 2017), де найбільш доцільні за агрокліматичними характеристиками галузі витісняються більш вигідними в умовах ринку.

3. 3 географічної точки зору відмічається низька континуальність у розповсюдженні інших типів сільського господарства, крім названих вище, що означає формування суцільного «поля» із зерно-олійною спеціалізацією від Близнюківського до Дергачівського району по вектору Південь--Північ і від Боровського до Красноградського району по вектору Схід--Захід. Певний виняток складає приміська зона м. Харків, де ще можна знайти деякі просторові закономірності у формуванні азональних типів, зорієнтованих на споживача.

4. Високий споживацький потенціал міст Харків, Куп'янськ, Красноград зумовлює попит на розвиток більш широкого спектра азональних 
галузей рослинництва і тваринництва, таких як вирощування цитрусових та тропічних культур, рису, міцелію гливи та печериці, овочевих та баштанних культур, садівництво та виноградарство, , бджільництво, кролівництво, рибництво. Проте розвиток цих галузей перебуває в зоні високого економічного ризику, оскільки вимагає високих витрат на підтримання спеціалізації, не притаманної для цієї природної зони.

5. Серед сучасних тенденцій формування сільськогосподарських районів Харківської області звертає на себе увагу поступова трансформація спеціалізації Куп'янського Приоскольського із зональної (зернові, соняшник) до приміської (молочно-м'ясне скотарство, овочівництво, птахівництво, рибництво). Значною мірою це пов'язане з близькістю потужних центрів споживання сільськогосподарської продукції у сусідній Донецькій області (Краматорськ, Слов'янськ, Дружківка та ін.), які в результаті воєнних дій втратили своїх традиційних постачальників.

6. 3 точки зору екосистемної динаміки завдяки розвитку ринкової економіки у вітчизняних агроекосистемах відбувся поступовий перерозподіл речовинно-енергетичних потоків із ви- щих трофічних рівнів (що відповідають консументам I порядку) на нижчі, що відповідають продуцентам. Таке збіднення видового різноманіття агроекосистем найскоріше спричинить у найближчому майбутньому ще більшу втрату грунтами їх природної родючості.

Виконані типологія сільськогосподарських підприємств і районування сільського господарства Харківської області може скласти наукову основу для подальшого аналізу відповідності спеціалізації агрокліматичним умовам із прямим виходом на кадастрові оцінки земель, а, отже, розробку законодавчого та економічного механізму землекористування в сільській місцевості України. Такі дослідження стають усе більш актуальними напередодні адміністративно-територіальної реформи і передачі сільськогосподарських земель у володіння сільських громад.

Подальші перспективи своїх досліджень автор пов'язує із сільськогосподарським районуванням територій інших областей лісостепової зони України і встановленням відповідності наявної спеціалізації ландшафтним особливостям території, а також екологічним оцінкам такої спеціалізації.

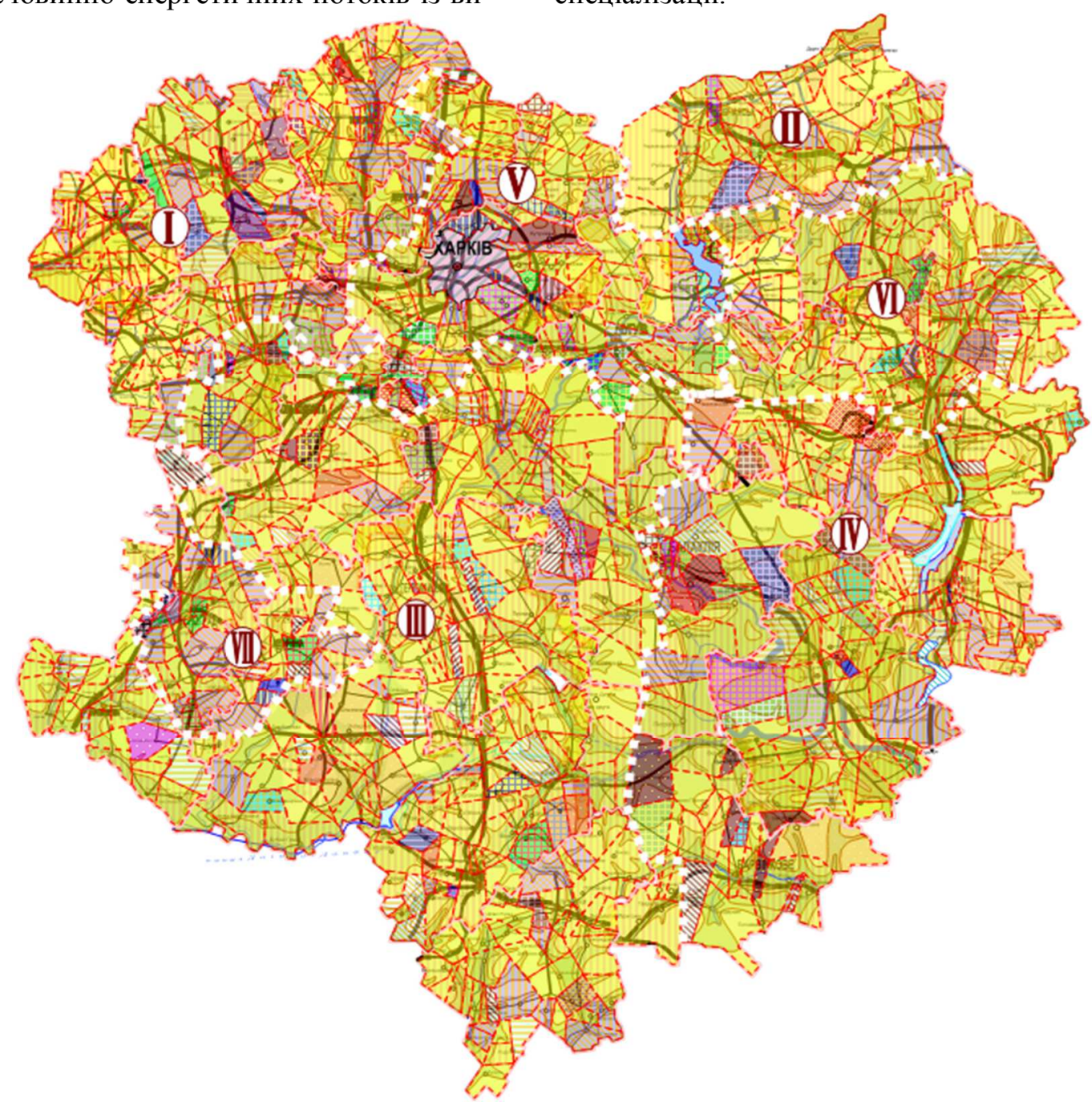

Рис.2. Виробничі типи сільськогосподарських підприємств та сільськогосподарські райони Харківської області станом на 2015 p. 


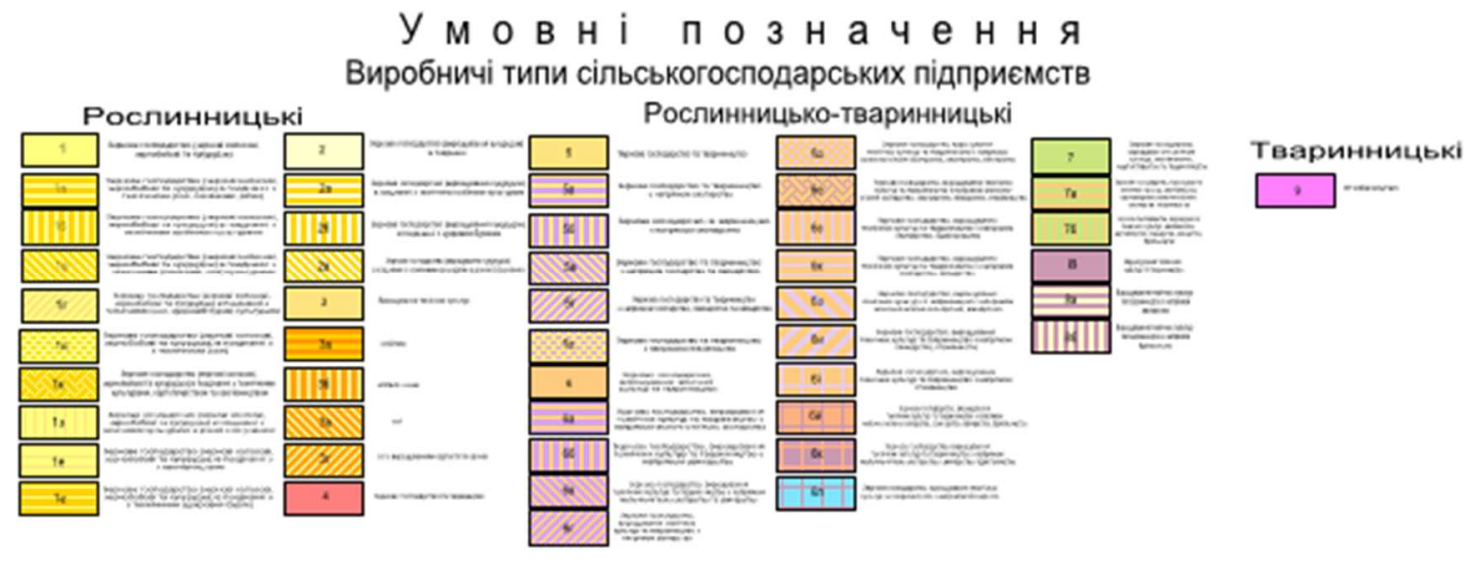

\section{Бібліографічні посилання}

Almeida, C., Mourão, M., Dessay, N., Lacques, A.-E., Monteiro, A., Durieux, L., Venturieri, A., Seyler, F. 2016. Typologies and Spatialization of Agricultural Production Systems in Rondônia, Brazil: Linking Land Use, Socioeconomics and Territorial Configuration. Land 2016, 5(2), 18; doi:10.3390/land5020018.

Bryzhko, V.G., Shkrebko, V.P. 2010. Koncepcija sovershenstvovanija territorial'noj organizacii prigorodnogo sel'skohozjajstvennogo proizvodstva $\mathrm{v}$ industrial'no razvitom regione [The concept of improving the territorial organization of suburban agricultural production in the industrialized region]. Agrarnyj vestnik Urala, 8(74), 28 - 30 (in Russian).

Coughlan Michael, R., Nelson Donald, R., Lonneman, Michael, Block Ashley, E. (2017). Historical Land Use Dynamics in the Highly Degraded Landscape of the Calhoun Critical Zone Observatory. Land. 6, 32; doi:10.3390/land6020032

Gudz' V.P., Shuvar I.A., Junyk A.V., Ryhlivs'kyj I.P., Mishhenko Ju.G., 2014. Adaptyvni systemy zemlerobstva [Adaptive farming systems]. Kyiv: Centr uchbovoi' literatury (in Ukrainian).

Gutorov, O.A., 2015 Vyrobnycha typizacija sil's'kogospodars'kyh pidpryjemstv u systemi integracijnyh vidnosyn [Industrial typification of agricultural enterprises in the system of integration relations]. Visnyk Harkivs'kogo nacional'nogo tehnichnogo universytetu sil's'kogo gospodarstva imeni Petra Vasylenka, 162, 130 - 138 (in Ukrainian).

Denysyk, G.I., 2001. Lisopole Ukrai'ny. [Forestfield of Ukraine ]. Vinnycja.: PP Vydavnyctvo «Tezys» (in Ukrainian).

Fermerskye hazjajstva v Umanskom rajone. 2017. [Farmers in Uman district]. Retrieved from: https:/tripoli.land/farmers/cherkasskaya/umanskiy?utf8 $=\% \mathrm{E} 2 \% 9 \mathrm{C} \% 93 \& \mathrm{q} \% 5 \mathrm{~B}$ categories id eq $\% 5 \mathrm{D}=\& \mathrm{q} \% 5 \mathrm{~B}$ catalog landing fields culture $\% 5 \mathrm{D}=\% \mathrm{D} 0 \% \mathrm{BF} \% \mathrm{D} 1 \%$ 88\%D0\%B5\%D0\%BD\%D0\%B8\%D1\%86\%D0\%B0\& $\mathrm{q} \% 5$ Blanding area sum between $\% 5 \mathrm{D}=500 \% 2 \mathrm{C} 1000$ $\& \mathrm{q} \% 5$ Berdpou eq $\% 5 \mathrm{D}$

Heckrath, G. , Djurhuus, J., Quine, T. A., Van Oost K., Govers G., Zhang Y. 2004. Tillage Erosion and Its Effect on Soil Properties and Crop Yield in Denmark. Journal of Environmental Quality. - 34(1), 312-324. doi:10.2134/jeq2005.0312.

Ibatullin, Sh.I., Shanin, O.V., Stepenko, O.V.,2014. Ocinka osnovnyh tendencij zonal'noi' specializacii' sil's'kogospodars'kogo zemlekorystuvannja v Ukrai'ni [Estimation of the main tendencies of zonal specialization of agricultural land use in Ukraine]. Ekonomika APK, 12, 12 - 21(in Ukrainian).

Karjagin, L.A., 2013. Ot praktiki territorial'noj organizacii sel'skogo hozjajstva $\mathrm{k}$ ustojchivomu razvitiju sel'skoj mestnosti [From the practice of the territorial organization of agriculture to the sustainable development of the countryside]. Vestnik Chuvashskogo universiteta, 4, 333 - 338 (in Russian).

Kostrovickij, E., 1970. Osnovnye principy i metody tipologii sel'skogo hazjajstva mira [Basic principles and methods of typology of world agriculture]. Izvestija AN SSSR. Serija geograficheskaja, 6, 162 - 168 (in Russian).

Lihvan, V., Dobrovol's'ka N., Kandyba Ju., 2013. Vyznachennja specializacii' sil's'kogo gospodarstva Harkivs'koi' oblasti [Determination of the specialization of agriculture in the Kharkiv region]. Chasopys social'no-ekonomichnoi' geografii', 14(1), 97 - 102 (in Ukrainian).

Ljashenko, G.V., 2011.Agroklimaticheskaja ocenka produktivnosti sel'skohozjajstvennyh kul'tur v Ukraine [Agroclimatic assessment of the productivity of agricultural crops in Ukraine]. Odessa: NNC IViV im. V.E. Tairova, (in Russian).

Naukovo-tehnichna rozrobka «Geoinformacijne modeljuvannja typologii' sil's'kogo gospodarstva Lisostepu Ukrai'ny z metoju rozrobky ekologichno tolerantnyh agroekosystem». 2016. [Scientific and technical development «Geoinformation modeling of the typology of agriculture of the forest-steppe of Ukraine in order to develop ecologically tolerant agro ecosystems»]. Retrieved from: http://lib.udau.edu.ua/handle/123456789/6194

Orozco-Ramírez, Q., Astier M., Barrasa, S. 2017. Agricultural Land Use Change after NAFTA in Central West Mexico. Land. 6, 66; doi:10.3390/land6040066.

Petrychenko, V.F., Zaryshnjak, A.S., Baljuk, S.A., Polupan M.I., Velychko V.A., Solovej V.B., 2013. Velykomasshtabne doslidzhennja g'runtovogo pokryvu Ukrai'ny - strategichnyj zahid efektyvnogo zbalansovanogo jogo vykorystannja [Large-scale study of Ukrwin's soil cover - a strategic measure of effective balanced use of it]. Visnyk agrarnoi' nauky, 5, 5 - 13 (in Ukrainian).

Problema utylizacii' opalogo lystja mist i vidhodiv tvarynnyc'kyh ferm i shljahy i'i' vyrishennja. 2017. [Problem of utilization of fallen leaves of cities and wastes of livestock farms and ways of its solution]. Retrieved from: http://ib.udau.edu.ua/handle/123456789/6257

Rivieccio, R., Sallustio, L., Massimo, P., Vizzarri, M., Marchetti, M. (2017). Where Land Use Changes Occur: Using Soil Features to Understand the Economic Trends in 
Agricultural Lands. Sustainability, 9(1). doi:10.3390/su9010078.

Sel'hozpredpryjatyja. [Agricultural enterprises]. 2017. Retrieved from:

https://ukrmap.org/year2016?query=\&obl_id=23\&rgn $\mathrm{id}=499$ \&adres $=\&$ vid $\mathrm{id}=0$ \&needarea $=$ on

Son'ko, S.P., 2015. Vyrobnycha typologija sil's'kogo gospodarstva Harkivs'koi' oblasti: trydcjat' rokiv potomu [The industrial typology of agriculture in the Kharkiv region: thirty years later]. Chasopys social'noekonomichnoi' geografii', 18 (1), 63 - 70 (in Ukrainian).

Son'ko, S.P., 2017. Vplyv vyrobnychogo typu sil's'kogo gospodarstva na rodjuchist' g'runtiv [Impact of production type of agriculture on soil fertility]. Proceedings of the International scientific conference, October, 23-24, Harkiv, Ukraine, 306 - 309 (in Ukrainian).

Son'ko, S.P., 2017. Geoinformacijne zabezpechennja ekologichnoi' ocinky specializacii' sil's'kogo gospodarstva lisostepovoi' zony Ukrai'ny [Geoinformation provision of ecological assessment of the specialization of agriculture in the forest-steppe zone of Ukraine]. Proceedings of the 7th Ukrainian scientific internet-conference, November, 13-20, Irpin' Ukraine, 67 - 80 (in Ukrainian).

Son'ko, S.P., Golubkina, O.M., 2014. Ekologo-ekonomichni osnovy reformuvannja agrarnogo sektora Ukrai'ny $\mathrm{v}$ umovah globalizacii'[Ecological and economic bases of reformation of agrarian sector of Ukraine in the conditions of globalization]. Innovacijno-tehnologichni aspekty formuvannja suchasnogo konkurentospromozhnogo APK Ukrai'ny. Uman': «Vizavi», 10 - 14 (in Ukrainian).

Son'ko, S.P., 2015. Dosvid stvorennja elementarnoi' GIS «Ocinka ekologichnogo vplyvu sil's'kogo gospodarstva na landshafty Cherkas'koi' oblasti» [The experience of the creation of elementary GIS "Assessment of the environmental impact of agriculture on the landscapes of Cherkasy region"]. Proceedings of the scientific conference «Perspektyvy rozvytku lisovogo i sadovoparkovogo gospodarstva», May, 20-21, Uman', Ukraine, $18-23$ (in Ukrainian).

Son'ko, S.P., 2000. Dosvid stvorennja elementarnoi' geoinformacijnoi' systemy $\mathrm{v}$ tekstovomu redaktori «Word» [The experience of creating an elementary geoinformation system in a word processor Word]. Proceedings of the scientific conference Ukrai'na ta global'ni procesy: geografichnyj vymir. April, 19-21, Kyi'v-Luc'k, Ukraine, 256 - 261 (in Ukrainian).

Son'ko, S.P., 2010. Znachennja naukovoi' spadshhyny S.A.Podolyns'kogo u formuvanni ujavlen' pro zbalansovane pryrodokorystuvannja[The value of S.A.Podolinsky's scientific heritage in the formation of ideas about balanced use of nature]. Visnyk Kryvoriz'kogo ekonomichnogo instytutu KNEU.- 4(24), 111 117 (in Ukrainian).

Son'ko, S.P., 2015. Ekologichni osnovy stvorennja al'ternatyvnyh agroekosystem [Ecological bases of creation of alternative agroecosystems]. Proceedings of the II International scientific conference «Vidnovlennja biotychnogo potencialu agroekosystem», October, 9, 2015, Dnipropetrovs'k, Ukraine, 169 - 172 (in Ukrainian).

Son'ko S.P., 2016. Ekologichni problemy suchasnogo sil's'kogo gospodarstva ta shljahy i'h vyrishennja [Ecological problems of modern agriculture and ways of their solution]. Agroelita, 1 (36), 52 - 53 (in Ukrainian).

Son'ko S.P., 2010. Koncepcija noosfernyh ekosystem jak prodovzhennja idej V.I.Vernads'kogo [The concept of noosphere ecosystems as a continuation of VI
Vernadsky's ideas]. Noosfera i cyvilizacija, 8-9(11), 230 - 241(in Ukrainian).

Son'ko, S.P., Maksymenko, N.V., 2012. Evoljucija mehanichnogo obrobitku g'runtu, jak golovnyj chynnyk planuvannja agrolandshaftu (ekologichni nadii' i rozcharuvannja) [Evolution of mechanical soil cultivation as the main factor in planning the agrolandscape (ecological hopes and disappointments)]. Visnyk HNU imeni V.N. Karazina, 1004, 7 - 22 (in Ukrainian).

Son'ko, S.P., Maksymenko, N.V., 2013. Prostorovi i chasovi mehanizmy antropogennoi' ekspansii' agrolandshaftu [Spatial and temporal mechanisms of anthropogenic expansion of agrolandscape]. Ljudyna ta dovkillja, 2 (15), 5 - 21(in Ukrainian).

Son'ko, S.P., 2017. Ocinka ekologichnogo vplyvu na agrolandshafty pevnyh spoluchen' galuzej u sil's'kogospodars'komu pidpryjemstvi [Assessment of ecological impact on agricultural landscapes of certain combinations of branches in an agricultural enterprise]. Proceedings of the Ukrainian scientific conference «Ekologichno bezpechne, vysokoproduktyvne vykorystannja g'runtu ta zastosuvannja dobryv»», Marth, 29, 2017, Uman', Ukraine. 81 - 83 (in Ukrainian).

Son'ko, S.P., 2017. Pro perspektyvy rozvytku agroekologii' u zabezpechenni zbalansovanogo pryrodokorystuvannja [On the prospects of agroecology development in ensuring balanced use of nature]. Proceedings of the I International scientific conference "Zbalansovane pryrodokorystuvannja: tradycii', perspektyvy i innovacii"' May, 18-19, 2017, Kyi'v, Ukraine, 139 - 142 (in Ukrainian).

Son'ko, S.P., 2003.Prostorovyj rozvytok socio-pryrodnyh system: shljah do novoi' paradygmy [Spatial development of socio-natural systems: the path to a new paradigm]. Kyiv: Nika-Centr(in Ukrainian).

Son'ko, S.P., 2015. Sil's'kogospodars'ke rajonuvannja - pershyj krok do zbalansovanogo pryrodokorystuvannja $\mathrm{v}$ agrosferi [Agricultural zoning is the first step towards a balanced use of natural resources in the agro-industry]. Visnyk Umans'kogo nacional'nogo universytetu sadivnyctva, 3(1), 106 - 112 (in Ukrainian).

Son'ko, S.P., Suhanova, I.P., 2015. Pragnennja do bioriznomanittja - novyj trend rozvytku stijkogo sil's'kogo gospodarstva [The pursuit of biodiversity is a new trend in agricultural development]. Proceedings of the Ukrainian scientific conference "Zberezhennja bioriznomanittja v konteksti stalogo rozvytku", October, 8 - 9, 2015, Cherkasy, Ukraine, 151 - 153 (in Ukrainian).

Son'ko, S.P., 1990. Jekonomiko-geograficheskoe issledovanie agropromyshlennoj integracii $\mathrm{v}$ svjazi $\mathrm{s}$ resheniem jekologicheskih problem Severo-Vostochnoj Ukrainy (Har'kovskaja oblast') [Economic-geographical study of agro-industrial integration in connection with the solution of environmental problems in Ukraine (Kharkiv region)].- Avtoref.kand.diss. geogr.nauk., 11.00 .02 jekonomicheskaja geografija. - M.:MGU im.M.V.Lomonosova.

Sweeney, D. W. (2017). Does 20 Years of Tillage and N Fertilization Influence Properties of a Claypan Soil in the Eastern Great Plains? Agricultural \& Environmental Letters,. 2(1). doi:10.2134/ael2017.08.0025.

Tarariko, Ju.O., Glushhenko, L.D., 2011. Modeljuvannja specializacii' agroekosystem za danymy dovgostrokovyh agrotehnichnyh doslidiv [Modeling of agro-ecosystem specialization according to long-term agrotechnical experiments]. Agroekologichnyj zhurnal, 4, 35-41 (in Ukrainian). 